\title{
ISLAMIC CHARACTER - BASED EDUCATION TO IMPROVE STUDENTS' LEARNING
}

\author{
Dr. Susanto, M.Si \\ Universitas Muhammadiyah Purwokerto \\ Indonesia
}

\begin{abstract}
There are several different ways students can show good character; Good Character can be little things such as holding a door open for others to pass through, helping a friend in need, and having honesty and integrity. Pearson \& Nicholson (2000), feel that there are three interconnected areas that represent good character: self, others, and the community. In order to built this interconection, especially for some islamic universities in Indonesia, islamic character based education is basically needed to improve students learning. This paper will explain the islamic caharacter - based islamic education that can be used for students learning
\end{abstract}

\section{Key words : Good Character, Islamic Education, Students'Learning}

\section{INTRODUCTION}

Teacher, parents, and the community members can help students understand the significance of a good character. To have students understand character, they must first recognize what forms a good character. According to Lickona, Schaps, and Lewis (2007), members of the school community should help students understand and recognize more about character through behaviors that can be taught, practiced and measured throughout school

According to Lockwood (1993), students who had been in good character education programs had typically performed well on assignments, such as worksheets or activity booklets, but when it came to real life situations these samestudents acted like they had no instruction at all in honesty, sharing, cooperation, and other character traits. Other studies have reached the same conclusions. Leming (1993) stated that character-building activities in schools had little effect on the students when it came to practice; their behavior outside of the character-building activities was the same as it had been before

\section{DISCUSSION OF ISLAMIC CHARACTER - BASED EDUCATION IN LEARNING}

There are some Character-Based islamic education that can be built by school to the students. Those are: being wise and positive thinking and being Fully human .

\section{Being Wise and Positive thinking}

We will feel restrained and burdened if we are in a small room. However, it is different when we are in the space area, we feel free and graceful. Descartes states: cogito ergo sum (I think then I exist, I exist therefore I think), this lead him to be the pioneer of Rationalism in Epistemology (Muslih, 2006).

That is the nature of the human mind, most students are narrow-minded, and do not want to view things positively. They give up before trying, feel lost before a game, feel frightened before the real things happen. The consequences that can be generated from is students become lazy for having class. Their main reason is that it is useless to study in college because it will be hard to find a job after they have graduated. 
Haught (2004) and Peters (2006) show their optimism that the problem can be overcome by encountering science and religion. The foundation for integration between science and faith in education is the most fundamental principle in all Islamic teachings: namely tauhid (Kartanegara, 2005). Therefore humans should receive education based on character (wisdom and faith).

The first principle of a good islamic based caracter is Being Wise and Positive thinking

In islamic education, Allah has inculcated nature to man for a wide view as the nature of Almighty God (al-Waasi '). However, fitrah ( nature) is now faded. The disease of al-wahn (the love of the world and the fear of death) has masked the fitrah. We must stay strong. We should be a generation who always think positively, in our knowledge, insightful as well as wisdom.

Understanding of many things shows that one has the depth of knowledge and the breadth of insight leading to the policy. It will bring the benefits of life as shown by the Messenger of God as an example in our lives. He had taught how to deal with different societies. One time he was asked by a friend, as Bukhari narrated: Friend asked: "O Messenger of Allah, what is the ultimate deed?", Then He replied, "Faith in Allah and His Messenger." Then the Companion asked again, anything else? "The Prophet replied," Jihad (struggling or striving ) in the way of Allah ", the companion asked again," Then what else? ", The Prophet replied," Mabrur Hajj. "

However, on another occasion, when the same question was given to him by another friend, his answer was different from what he had been said before. "O Messenger of Allah, what is the best deed?" He replied "Pray in due time, then obey both parents, then jihad in the way of Allah".

In that case we get a lesson on how to give an answer to someone according to their quality of understanding and faith. The history shows how widespread the horizon of view and wisdom of the Messenger of Allah. The wise nature leads to a fair attitude which is close to taqwa (God Consciousness).

\section{Being fully humans}

The second good Islamic based education charater is being a fully human, it meas that students should understand their nature as a human

Allah SWT has glorified man by giving him a special gift, that is ruh or spirit. Since a man has a soul, then man has qudrah (ability) to interact with the supernatural (metaphysical) reality. This is different from animals; they are only able to sense the environment. With that gift, men can have a view (tashawwur), thought (fikrah) orientation (ittijah), this causes humans to have a wide and profound action. If the above abilities are based on faith, then humans can distinguish between good or bad, right or wrong, halal (legitimate) or haram (illegitimate) known as furqon. But if it is not based on faith, it will bring human into an ignorant (jahiliyah) life (life with full of darkness) and decrease the degree of humanity. Allah SWT creates human in the best physical and spiritual system in order not to become ignorant man, then it requires physical and spiritual nutrition.

The belief that humans are special beings and choices causes him to be aware that they are different from other beings in terms of knowledge. Man is a reflection of the spirit with the will and selective power inside his soul (Mutahhari, 2002). Asy'arie (2006) states that basically religion on earth has a noble purpose to convey the holy messages of God, the most important of all is the faith that will lead to grace, happiness and liberation. Nowadays, the advancement of science in education has brought humans to the symptoms of dehumanization, even the possibility of changing the essence of humanity itself (Suriasumantri, 2005). 
Therefore education requires basic wisdom and faith.

A good man always does what God wants at any time and at any time, as Emil Brunner (Rachels, 2008) states. Therefore when a man lost his spirit or is spearated from his Lord, then he will be a creature who lives in a slender. In order to return to the entire of his soul, body and the breadth of wisdom, it needs these following concrete steps to be taken:

a. Stuents must realize that he is a very small part (point) in this universe. stuents is unable to reach the breadth of His creation, His goodness, His knowledge, His mercy and forgiveness. Man cannot make himself like a frog underneath coconut shell. Man must not stop inquiring or learning. As it is stated in Ar Rahman (55): 33

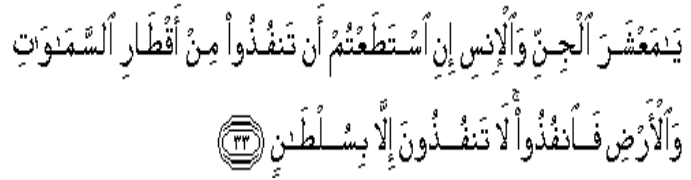

It means: " O company of jinn and mankind, if you are able to pass beyond the regions of the heavens and the earth, then pass. You will not pass except by authority [from Allah ]".

b. Stuents must realize that his presence in this world is not without any cause. There is the Supreme Being who presents it, that is Allah SWT. Starting from the creation of the fetus and grow it into infant, toddler, adolescent, adult, and elderly. Man must defer to to the phenomenon of His creator.As stated in Al Baqarah (2): 28

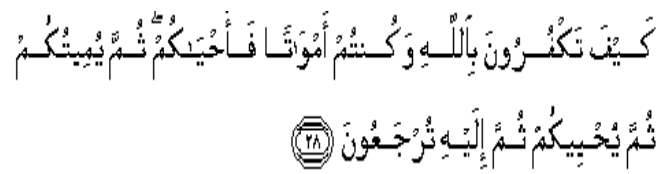

It means: "How can you disbelieve in Allah when you were lifeless and $\mathrm{He}$ brought you to life; then He will cause you to die, then $\mathrm{He}$ will bring you [back] to life, and then to Him you will be returned".

c. Students must continuously recite the Nafsiyah verses (related to spiritual) which presents humans are created of physical and spiritual structures. It will affect to humans that in running this life should meet the physical and spiritual needs as a whole and balanced.It is stated in QS. Shaad (38) : 71-72

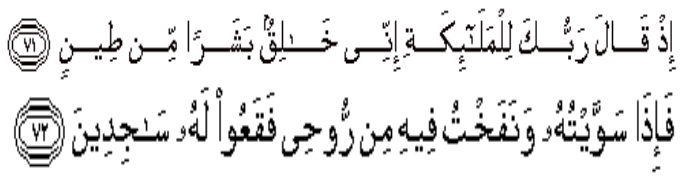

"[So mention] when your Lord said to the angels, Indeed, I am going to create a human being from clay. So when I have proportioned him and breathed into him of My [created] soul, then fall down to him in prostration."

d. Since human is created from very valuable material, therefore its presence in this world won't be just a play but it brings a noble life mission. Thus students shuld build a noble character, suc as stated in $\mathbf{Q S}$. $\mathbf{A l}$ Mu'minun (23) : 115-116

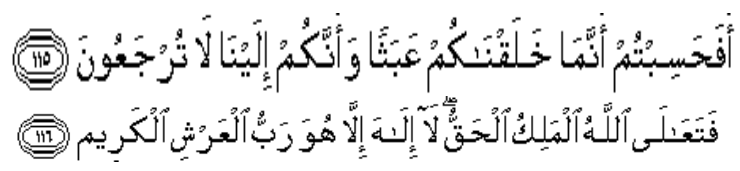

"Then did you think that We created you uselessly and that to Us you would not be returned?. So exalted is Allah, the Sovereign, the Truth; there is no deity except Him, Lord of the Noble Throne.

And also in QS. Adz-Dzaariyaat (51) : 56

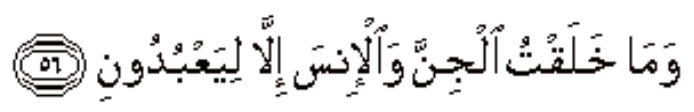


"And I did not create the jinn and mankind except to worship Me.".

In order to succeed in traveling the world (rihyatul hayah) and survived in the Hereafter, humans need to obey the warnings of Allah SWT, He is the one who gives life and the omniscient. As it is stated in QS. Al Baqarah (2) : 38-39

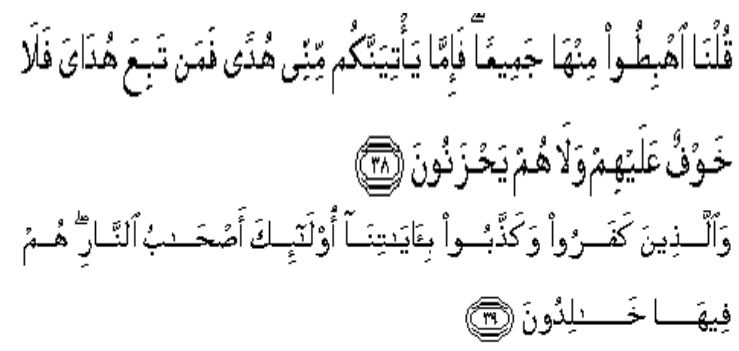

"We said, Go down from it, all of you. And when guidance comes to you from $M e$, whoever follows My guidance - there will be no fear concerning them, nor will they grieve. And those who disbelieve and deny Our signs - those will be companions of the Fire; they will abide therein eternally."

e. Stuents must realize that the final result of the test in this world is to get an award (passed) and enter His heaven, or fail and enter into His hell. If there is no proper recompense, then Allah SWT would be unfair. Human beings are different in term of obedient and disobedient to Allah SWT. Someone will end his life according to his habit in the world. Humans who usually conduct a sin will die in a condition of $s u$ 'ul khatimah, in the other hand if he is regularly obedient to Him, he will die in husnul khatimah. Therefore humans must be selective in choosing and determining their habits.

f. Students must often look at their past to take the lesson and guidance to success in the future. Man needs to study history more carefully so that he does not make the same mistake twice. As it is stated in $\mathbf{Q S}$. Ali Imran (3) : 137

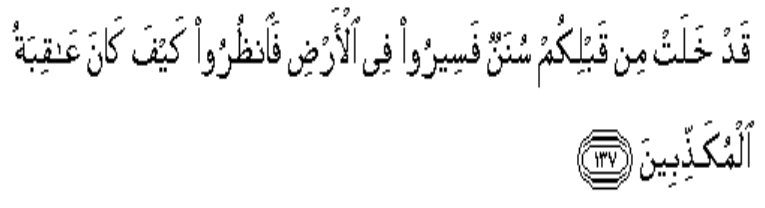

"Similar situations [as yours] have passed on before you, so proceed throughout the earth and observe how was the end of those who denied."

The standard knowledge and the horizon of a man's mindset is when he can answer satisfactorily five basic questions: (1) who is he? (2) Who creates him? (3) What is he in the world for? (4) How does he run his life in this world? (5) Where will he go after living in this world?. If the five fundamental questions above cannot be properly answered to satisfy his mind and heart, then he will experience the crisis of life meaning (thirst and life shaking in this world).

\section{CONCLUSION}

From this paper it can be concluded that the islamic caharacter - based islamic education can be used to improve students learning, especially for islamic school that is in progress to built students charater

\section{REFERENCES}

Asy'arie, Musa. 2006. Agama untuk Pembebasan Kemiskinan dalam Ilmu, Etika Agama : Menyingkap Tabir Alam dan Manusia. Yogyakarta: Program Studi dan Lintas Budaya (CRCS) Sekolah Pascasarjana, Universitas Gadjah Mada. ISBN : 97925-5285-5.

Haught, John F. 2004. Perjumpaan Sains dan Agama : Dari Konflik ke Dialog. Bandung: Mizan Pustaka. ISBN : 979433-371-9. 
Kartanegara, Mulyadi. 2005. Integerasi Ilmu : Sebuah Rekontruksi Holistik. Bandung: Arasy Mizan Pustaka. ISBN 979-3551-11-9.

Leahy, Louis. 2002. Horison Manusia. Yogyakarta: Penerbit Kanisius. ISBN : 979-21-0559-1.

Leming, J. (1993). In search of effective character education. Educational Leadership, 51, 63- 71.

Lickona, T., Schaps, E., \& Lewis, C. (2007).

Character education partnership $(C E P)$ : Eleven principles of effective character education. Retrieved April 15, 2016, from:

ww.forcharacter.comlpageI2

Lockwood, A. L. (1993). A letter to character educators. Educational Leadership, $51,72-75$

Muslih, Muhammad. 2004. Filsafat Ilmu : Kajian atas Asumsi Dasar, Paradigma dan Kerangka Teori Ilmu Pengetahuan. Yogyakarta: Blukar. ISBN : 979-3494-05-0.

Muthahhari, Murtadha. 2002. Manusia dan Alam Semesta : Konsepsi Islam Tentang Jagat Raya. Jakarta: Lentera. ISBN : 979-3018-12-7.

Pearson, Q., \& Nicholson, J. (2000). Comprehensive character education in the elementary school: Strategies for administrators, teachers, and counselors. Journal of Humanistic Counseling, Education \& Development, 38, 243. Retrieved April 8, 2016, from: http://ezproxy.1ib.uwstout.edu

Peter, Ted. 2006. Ilmu Pengetahuan dan Iman : Dari Peperangan Menuju Kesesuaian dalam Tuhan, Alam, Manusia : Prespektif Sains dan Agama. Bandung: Mizan Pustaka. ISBN : 979433-409-X.
Rachels, James. 2004. Filsafat Moral. Yogyakarta: Penerbit Kanisius. ISBN : 979-21-0949-8.

Suriasumantri, Jujun S. 2005. Filsafat Ilmu Sebuah Pengantar Populer. Jakarta:Pustaka Sinar Harapan. 